\title{
Role of family susceptibility, occupational and family histories and individuals' blood groups in the development of silicosis*
}

\author{
M H NOWEIR, M MOSELHI, AND E K AMINE \\ From the Occupational Health Department, High Institute of Public Health, University of Alexandria, \\ Egypt
}

ABSTRACT A previous investigation has shown that family susceptibility and occupational and family histories have a decisive role in the development of byssinosis among workers exposed to flax dust. Results of investigation of silicosis in 814 male workers exposed to silica-bearing dust showed that family susceptibility has an important role in the development of silicosis among examined workers, and workers whose fathers had an occupational history of exposure to silica-bearing dust were more resistant to the development of the disease than those with non-exposed fathers. The degree of consanguinity of parents and individuals' blood groups, also, have a role. Workers with cousin parents were relatively highly susceptible to the development of silicosis as well as workers with blood groups "O" or "AB." It has been concluded that the investigated factors might have a role in the development of other occupational diseases and further investigations are indicated.

Individual susceptibility has been suggested as a factor that may have a role in the development of silicosis among workers exposed to silica dust. The individual's idiosyncrasy and the immunological reactivity of the subject are important factors in determining the character and severity of reaction of the subject to inhaled particles, ${ }^{1}$ and susceptibility may be inherited within the family. For example, family susceptibility is known to have an impact on the incidence of tuberculosis, gout, rheumatic fever, diabetes mellitus, and epilepsy. ${ }^{23}$ A previous communication ${ }^{4}$ has indicated that family susceptibility has a role in the incidence of byssinosis among workers exposed to flax dust.

Another factor known to affect the prevalence of some diseases is the degree of parental consanguinity. ${ }^{5}$ In the Egyptian rural areas consanguineous marriages are prevalent for historic, geographic, and social reasons. This results in an extended family pattern that has been reported to constitute $31.2 \%$ of

*Presented at the 19th International Congress on Occupational Health, Dubrovnik, Yugoslavia, 25-30 September 1978.

Supported by the USPHS PL-480 Agreement No 03-003-C.

Received 25 May 1979

Accepted 28 February 1980 rural families. ${ }^{6}$ The harmfulness of consanguineous marriages rests on the increase of genetic effects since it reactivates recessive hereditary factors. ${ }^{7}$ Rare recessive diseases such as albinism, phenylketonuria, amaurotic idiocy, ichthyosis congenita, congenital total colour blindness, and xeroderma pigmentosa show a pronounced increase among offspring of consanguineous parents. ${ }^{8}$ On the other hand, the incidence of erythroblastosis fetalis was reduced by $13 \%$ as a result of cousin marriages. ${ }^{9}$

A factor that contributes to the reduced prevalence of byssinosis is the father's history of exposure to flax dust. ${ }^{4}$ Workers whose fathers had a history of exposure to flax dust were relatively resistant to the development of the disease. Within such groups subjects whose fathers had had byssinosis were more resistant to the development of the disease than workers whose fathers had not.

The incidence of some diseases, especially those with known hereditary factors, is also affected by the distribution of the individuals' ABO blood groups. For example, bronchiectasis, portal cirrhosis, ${ }^{10}$ hypercholesterolaemia, ${ }^{11}$ coronary heart diseases, ${ }^{12}$ carcinoma of the stomach, ${ }^{13}$ and schizophrenia ${ }^{14}$ have been associated with group A. Chronic peptic ulcer, especially duodenal, ${ }^{15}$ rheumatic heart, and 
bilharzial hepatic fibrosis ${ }^{16} 17$ have been associated with group $\mathbf{O}$. Other diseases with a known inherited tendency-for instance, hypertension-have no significant difference in the ABO blood group distribution. ${ }^{18}$

The present study was intended to investigate the role of family hereditary characteristics, consanguinity, family occupational history, and the ABO blood group distribution on the development of silicosis among workers exposed to silica-bearing dust. It was expected that data developed from this investigation, together with those of the previous investigation, ${ }^{4}$ would help to determine the role of the investigated parameters on the development of some occupational diseases.

\section{Methodology}

A group of 814 male workers exposed to silicabearing dust in a plant producing refractories located in a village $70 \mathrm{~km}$ south of Cairo was investigated. The plant has been in operation for about 75 years, and workers belonging to different generations from the same families of the village have been employed in it ever since.

Each workers was interviewed for his social, personal, familial, occupational, and past and present medical histories and smoking habits, as well as for the occupational and medical histories of his father, grandfather, sons, and other relatives who had been employed in the same plant, with emphasis on the history of respiratory diseases, allergy, and smoking. Workers were also questioned about the degree of consanguinity of their parents. This was followed by a medical examination and chest radiography. The interview and the medical examination were conducted without knowledge of the results of the examination of his relatives or fellow workers. Workers of the same family were grouped together and further interviewed to double check the degree of consanguinity between the different members of the family and their occupational history.

Silicosis was diagnosed among examined workers according to UICC/Cincinnati classification. ${ }^{19}$ The blood group of each worker was obtained from his identification card or from his personal record in the plant or both.

\section{Results}

Table 1 illustrates the prevalence of silicosis among some of the families included in the study. Families with four or more workers employed in the plant and exposed to dust are included in the same table. The

Table 1 Prevalence of silicosis in different families

\begin{tabular}{|c|c|c|c|c|c|c|}
\hline \multirow[t]{2}{*}{ Family No } & \multirow{2}{*}{$\begin{array}{l}\text { No of subjects } \\
\text { exposed to silica } \\
\text { dust }\end{array}$} & \multirow{2}{*}{$\begin{array}{l}\text { Age }(y r) \\
(\text { mean } \pm S D)\end{array}$} & \multirow{2}{*}{$\begin{array}{l}\text { Duration of exposure }(y r) \\
(\text { mean } \pm S D)\end{array}$} & \multicolumn{3}{|c|}{ Silicotic subjects } \\
\hline & & & & No & $\%$ & \\
\hline 1 & 8 & $37 \cdot 1 \pm 7.6$ & $12 \cdot 0 \pm 2 \cdot 8$ & 0 & 0 & \\
\hline 2 & 5 & $44.0 \pm 18.6$ & $20.3 \pm 9.9$ & 0 & 0 & \\
\hline 3 & 4 & $36.5 \pm 6.3$ & $14.7 \pm 3.6$ & $\mathbf{0}$ & $\mathbf{0}$ & \\
\hline 4 & 5 & $38 \cdot 0 \pm 7 \cdot 3$ & $17 \cdot 2 \pm 4.0$ & 0 & $\mathbf{0}$ & \\
\hline 5 & 5 & $48 \cdot 1 \pm 15 \cdot 5$ & $21 \cdot 1 \pm 12.6$ & 0 & $\mathbf{0}$ & \\
\hline 7 & 4 & $43.2 \pm 9.7$ & $18.5 \pm 9.9$ & 0 & 0 & \\
\hline 8 & 5 & $33 \cdot 9 \pm 12 \cdot 1$ & $16 \cdot 3 \pm 7 \cdot 2$ & 1 & $20 \cdot 0$ & \\
\hline 9 & 4 & $30.8 \pm 5.5$ & $11.7 \pm 8.2$ & 1 & $25 \cdot 0$ & \\
\hline 10 & 4 & $43.7 \pm 12.6$ & $18 \cdot 1 \pm 12 \cdot 2$ & 1 & $25 \cdot 0$ & \\
\hline 11 & 5 & $36.9 \pm 8.4$ & $15.3 \pm 6.9$ & 2 & $40 \cdot 0$ & \\
\hline 12 & 5 & $48 \cdot 2 \pm 11 \cdot 3$ & $17 \cdot 5 \pm 5.7$ & 2 & $40 \cdot 0$ & \\
\hline 13 & 5 & $40 \cdot 2 \pm 7 \cdot 2$ & $13.4 \pm 6.3$ & 2 & $40 \cdot 0$ & \\
\hline 14 & 7 & $35 \cdot 3 \pm 4 \cdot 7$ & $14.9 \pm 8.7$ & 3 & $42 \cdot 9$ & \\
\hline 15 & 7 & $48.0 \pm 9.9$ & $17 \cdot 8 \pm 10 \cdot 1$ & 3 & $42 \cdot 9$ & \\
\hline 18 & 4 & $46 \cdot 2 \pm 22 \cdot 21$ & $11.8 \pm 11.0$ & 2 & $50 \cdot 0$ & \\
\hline 19 & 5 & $44 \cdot 4 \pm 7 \cdot 3$ & $23.2 \pm 9.9$ & 3 & $60 \cdot 0$ & \\
\hline 20 & 6 & $43 \cdot 2 \pm 8 \cdot 1$ & $20.0 \pm 7.8$ & 4 & $66 \cdot 7$ & \\
\hline 21 & 6 & $35 \cdot 8 \pm 11 \cdot 7$ & $13 \cdot 2 \pm 5.9$ & 4 & $66 \cdot 7$ & \\
\hline 22 & 6 & $41.7 \pm 7 \cdot 3$ & $19.5 \pm 7.9$ & 4 & $66 \cdot 7$ & \\
\hline 23 & 7 & $37 \cdot 7 \pm 8 \cdot 21$ & $15 \cdot 7 \pm 7 \cdot 3$ & 5 & $71 \cdot 4$ & \\
\hline 24 & 4 & $44.5 \pm 12.7$ & $21.4 \pm 9.2$ & 3 & 75.0 & \\
\hline 25 & 4 & $33.7 \pm 5.1$ & $13.0 \pm 3.7$ & 3 & $75 \cdot 0$ & \\
\hline 26 & 4 & $33.8 \pm 6.8$ & $9.8 \pm 4.7$ & 3 & $75 \cdot 0$ & \\
\hline 27 & 5 & $35.8 \pm 12.7$ & $16.4 \pm 11 \cdot 3$ & 4 & $80 \cdot 0$ & \\
\hline 28 & 6 & $47 \cdot 2 \pm 13.5$ & $23.5 \pm 8.7$ & 5 & 83.7 & \\
\hline 29 & 7 & $43.3 \pm 8.4$ & $22.8 \pm 15.0$ & 6 & $85 \cdot 7$ & \\
\hline 30 & 8 & $47.1 \pm 5.4$ & $22.8 \pm 8.5$ & 7 & $87 \cdot 5$ & \\
\hline 31 & 4 & $47.0 \pm 14.8$ & $23.0 \pm 11.3$ & 4 & $100 \cdot 0$ & \\
\hline 32 & 6 & $47.3 \pm 8.4$ & $28.4 \pm 15.2$ & 6 & $100 \cdot 0$ & \\
\hline 33 & 4 & $42.5 \pm 10.7$ & $17.6 \pm 10.6$ & 4 & $100 \cdot 0$ & \\
\hline
\end{tabular}


Table 2 Subjects with silicosis in some families

\begin{tabular}{|c|c|c|c|c|c|}
\hline Family & Subject & Position in family & Age & Duration of exposure & Silicosis \\
\hline \multirow[t]{8}{*}{$1^{*}$} & 1 & Brother (a) & 38 & 14 & - \\
\hline & 2 & Brother (a) & 37 & 12 & - \\
\hline & 3 & Brother (b) & 46 & 15 & - \\
\hline & 4 & Brother (b) & 45 & 14 & - \\
\hline & 5 & Cousin & 40 & 14 & - \\
\hline & 6 & Cousin & 39 & 11 & - \\
\hline & 7 & Cousin & 27 & 7 & - \\
\hline & 8 & Cousin & 25 & 9 & - \\
\hline \multirow[t]{8}{*}{6} & 1 & Brother (a) & 50 & 34 & - \\
\hline & 2 & Brother (a) & 43 & 12 & - \\
\hline & 3 & Brother (a) & 30 & 4 & - \\
\hline & 4 & Cousin & 45 & 19 & - \\
\hline & 5 & Cousin & 40 & 12 & - \\
\hline & 6 & Cousin & 38 & 12 & - \\
\hline & 7 & Cousin & 36 & 13 & - \\
\hline & 8 & Cousin & 33 & 13 & - \\
\hline \multirow[t]{7}{*}{15} & 1 & Brother (a) & 40 & 19 & + \\
\hline & 2 & Brother (a) & 35 & 16 & - \\
\hline & 3 & Brother (b) & 32 & 15 & + \\
\hline & 4 & Brother (b) & 30 & 14 & - \\
\hline & 5 & Cousin & 40 & 18 & - \\
\hline & 6 & Cousin & 40 & 12 & - \\
\hline & 7 & Cousin & $\therefore$ & 16 & + \\
\hline \multirow[t]{6}{*}{28} & 1 & Cousin & 53 & 40 & + \\
\hline & 2 & Cousin & 49 & 32 & + \\
\hline & 3 & Cousin & 47 & 31 & + \\
\hline & 4 & Cousin & 45 & 25 & + \\
\hline & 5 & Cousin & 33 & 4 & - \\
\hline & 6 & Cousin & 33 & 5 & + \\
\hline \multirow[t]{4}{*}{33} & 1 & Brother (a) & 52 & 33 & $\div$ \\
\hline & 2 & Brother (a) & 50 & 16 & + \\
\hline & 3 & Cousin & 39 & 13 & + \\
\hline & 4 & Cousin & 29 & 9 & + \\
\hline
\end{tabular}

* Family 1 (as an example) includes the sons of six fathers-(a), (b), and four other fathers-who are all brothers. Both fathers (a) and (b) have two sons working in the plant and each of the other four fathers has only one son in the plant; all the sons of the different fathers are cousins to each other.

members of some families (Nos 1-7) did not develop silicosis despite their prolonged duration of exposure to dust (mean $12 \cdot 0-21 \cdot 1$ years). On the other hand, all members of other families (31-33) had developed silicosis (mean duration of exposure 17.6-28.4 years). The prevalence of the disease varied among other families to different extents. The mean age and duration of exposure of several families were nearly similar, while the prevalence of silicosis was drastically different-for example, families $1,2,4$, and 5 versus families $22,25,27$, and 33 . In a few familiesfor instance, family 26-the mean duration of exposure was low $(9.8$ years) while the prevalence of silicosis was high $(75 \%)$.

Table 2 presents examples of the data of some selected families $(1,6,15,28$, and 33). Silicosis did not occur in any of the eight members of each of the families 1 or 6 , although their duration of exposure varied from seven to 15 years and four to 34 years for the two families respectively. On the other hand, five out of the six members of family 28 and all members of family 33 developed silicosis, although the duration of exposure of some of their members was as low as five years. All these families included brothers and cousins. In other words, the members $4^{*}$ of some families were highly susceptible to development of silicosis, while the members of other families were resistant. Again, the importance of the duration of exposure in the development of the disease seems to be masked by the family susceptibility among investigated workers. The significance of this susceptibility was further tested and illustrated (table 3 ). The brothers, cousins, and far relative members in the different families were grouped into pairs (older and younger) and classified as either

Table 3 Prevalence of silicosis among examined workers versus their degree of consanguinity

\begin{tabular}{llccc}
\hline & & Silicotic & Free & Total \\
\hline & & Older brothers $^{*}$ & \\
Younger* & Silicotic & 56 & 15 & 71 \\
brothers & Free & 9 & 58 & 67 \\
& Total & 65 & 73 & 138 \\
& & Older cousins* & & \\
Younger* & Silicotic & 67 & 29 & 96 \\
cousins & Free & 25 & 73 & 98 \\
& Total & 92 & 102 & 194 \\
Younger far & Silicotic & 65 & 5 & \\
relatives & Free & 1 & 20 & 70 \\
& Total & 66 & 25 & 21 \\
& & &
\end{tabular}

*Marginal $\chi^{2}$ not significant. 
Table 4 Mean age and duration of exposure of examined workers

\begin{tabular}{|c|c|c|c|c|c|c|c|c|}
\hline $\begin{array}{l}\text { Degree of } \\
\text { consanguinity }\end{array}$ & & No & $\begin{array}{l}\text { Age }(y r) \\
(\text { mean } \pm S D)\end{array}$ & $t$ & $p$ & $\begin{array}{l}\text { Duration of } \\
\text { exposure }(y r) \\
(\text { mean } \pm S D)\end{array}$ & $t$ & $p$ \\
\hline Brothers & $\begin{array}{l}\text { Older } \\
\text { Younger }\end{array}$ & $\begin{array}{l}138 \\
138\end{array}$ & $\begin{array}{l}47.6 \pm 6.8 \\
35.4 \pm 8 \cdot 1\end{array}$ & $13 \cdot 5700$ & $<0.01$ & $\begin{array}{l}21.5 \pm 8.2 \\
14.8 \pm 6.5\end{array}$ & $7 \cdot 5288$ & $<0.01$ \\
\hline Cousins & $\begin{array}{l}\text { Older } \\
\text { Younger }\end{array}$ & $\begin{array}{l}194 \\
194\end{array}$ & $\begin{array}{l}48 \cdot 9 \pm 5 \cdot 3 \\
37 \cdot 3 \pm 6 \cdot 1\end{array}$ & $21 \cdot 8867$ & $<0.01$ & $\begin{array}{l}22 \cdot 7 \pm 7 \cdot 3 \\
15 \cdot 8 \pm 5 \cdot 9\end{array}$ & $10 \cdot 2520$ & $<0.01$ \\
\hline Far relatives & $\begin{array}{l}\text { Older } \\
\text { Younger }\end{array}$ & $\begin{array}{l}91 \\
91\end{array}$ & $\begin{array}{l}48 \cdot 1 \pm 9 \cdot 3 \\
36 \cdot 2 \pm 10 \cdot 2\end{array}$ & 8.0503 & $<0.01$ & $\begin{array}{r}22.9 \pm 11.3 \\
13.3 \pm 9.7\end{array}$ & $6 \cdot 1578$ & $<0.01$ \\
\hline
\end{tabular}

silicotic or free. The figures in the table represent these pairs. The cousins listed in the table represent those whose parents are brothers. The significance of the difference between the subgroups was tested using the marginal $\chi^{2}$ test. In many families there were more than two brothers, cousins, or far relatives, and so the middle one might be counted once as an older subject and again as a younger subject. Also, the same subject might be counted once as brother or cousin, or both, and again as cousin or far relative, or both, according to the degree of consanguinity with the other family member with whom he was matched. Comparisons of age and duration of exposure of the older and younger family members-that is, brothers, cousins, or far relatives-are also presented in table 4 . Although the older family members were exposed to silica-bearing dust for significantly longer durations than the younger ones (table 4), the prevalence of silicosis in both groups - that is, older and youngerwas not statistically different (table 3 ).

Table 5 presents the prevalence of silicosis among examined workers in relation to the degree of consanguinity of their parents. When the parents were cousins, the sons were more susceptible to the development of silicosis than if the parents were either far relatives or not related. The prevalence of silicosis in the first group was $52.9 \%$, which was statistically higher than the $36.1 \%$ and $40.0 \%$ of the other two groups respectively. The prevalence rates of the disease in the latter two groups were not statistically different. The mean age and duration of exposure and the ratio of the smokers were comparable among the three different groups.

Table 6 shows the prevalence of silicosis among examined workers versus history of fathers' exposure to silica-bearing dust. With the exception of the group of workers with exposure duration of less than 10 years, the prevalence of silicosis was higher between those with fathers who have had no history of exposure than those with exposed fathers. The difference was significant after exposure to dust for periods longer than 20 years, where the difference was further magnified with prolongation of the duration of exposure. For the group of workers with duration of exposure of less than 10 years, however, the prevalence of silicosis was significantly lower among workers with non-exposed fathers than in those with exposed fathers. No significant differences were observed in the mean age and percentage smokers among examined workers in the matched subgroups.

Table 7 illustrates the prevalence of silicosis among examined workers relative to their blood groups. Despite the close similarity in age, duration of exposure, and the percentage smokers among workers of different blood groups, the results suggest that the outcome of exposure to silica dust was somehow related to the workers' blood groups. Workers with blood groups $\mathrm{O}$ or $\mathrm{AB}$ were the most susceptible to the development of the disease, since the prevalence of silicosis was $49.7 \%$ and $49 \cdot 2 \%$ in these two groups respectively. The prevalence of the disease was less among workers with blood groups B $(43.2 \%)$ and was least among workers with blood group A $(36.2 \%)$. Visual inspection of the data of the individual families further supported this observation. Prevalence of silicosis was lower in families with a predominant blood group $\mathrm{A}$ among their members than in other families. The relatively few number of members in the different families, however, did not allow testing the association of blood groups and the

Table 5 Prevalence of silicosis among examined workers versus degree of consanguinity of their parents

\begin{tabular}{|c|c|c|c|c|c|c|}
\hline \multirow{2}{*}{$\begin{array}{l}\text { Parents' } \\
\text { consanguinity }\end{array}$} & \multirow{2}{*}{$\begin{array}{l}\text { No } \\
\text { examined }\end{array}$} & \multirow{2}{*}{$\begin{array}{l}\text { Age }(y r) \\
(\bar{X} \pm S D)\end{array}$} & \multirow{2}{*}{$\begin{array}{l}\text { Duration of } \\
\text { exposure }(y r) \\
(\bar{X} \pm S D)\end{array}$} & \multirow{2}{*}{$\begin{array}{l}\text { Smokers } \\
(\%)\end{array}$} & \multicolumn{2}{|c|}{ Silicotics } \\
\hline & & & & & $\mathrm{No}$ & $\%$ \\
\hline $\begin{array}{l}\text { Cousins } \\
\text { Far relatives } \\
\text { No relation }\end{array}$ & $\begin{array}{r}261 \\
83 \\
470\end{array}$ & $\begin{array}{l}38.5 \pm 9.9 \\
38.5 \pm 9.4 \\
39.9 \pm 9.9\end{array}$ & $\begin{array}{l}15 \cdot 6 \pm 7 \cdot 3 \\
14.7 \pm 7 \cdot 0 \\
16.6 \pm 6.9\end{array}$ & $\begin{array}{l}61 \cdot 7 \\
68 \cdot 7 \\
73 \cdot 8\end{array}$ & $\begin{array}{r}138 \\
30 \\
188\end{array}$ & $\begin{array}{l}52 \cdot 9^{\mathrm{a}} \\
36 \cdot 1^{\mathrm{b}} \\
40 \cdot 0^{\mathrm{b}}\end{array}$ \\
\hline
\end{tabular}

a,b All percentages for a given class of parent's consanguinity without common superscript differ significantly at $p<0.05$. 
Table 6 Prevalence of silicosis among examined workers versus exposure history of fathers to silica-bearing dust

\begin{tabular}{|c|c|c|c|c|c|c|c|c|c|c|}
\hline \multirow{3}{*}{$\begin{array}{l}\text { Duration of } \\
\text { exposure }(y r)\end{array}$} & \multicolumn{5}{|c|}{ Father exposed $\mathrm{a}$} & \multicolumn{5}{|c|}{ Father not exposed $\mathrm{b}$} \\
\hline & \multirow{2}{*}{$\begin{array}{l}\text { No } \\
\text { examined }\end{array}$} & \multirow{2}{*}{$\begin{array}{l}\text { Age }(y r) \\
(\text { mean } \pm S D)\end{array}$} & \multirow{2}{*}{$\begin{array}{l}\text { Smokers } \\
(\%)\end{array}$} & \multicolumn{2}{|c|}{ Silicosis } & \multirow{2}{*}{$\begin{array}{l}\text { No } \\
\text { examined }\end{array}$} & \multirow{2}{*}{$\begin{array}{l}\text { Age }(y r) \\
(m e a n \pm S D)\end{array}$} & \multirow{2}{*}{$\begin{array}{l}\text { Smokers } \\
(\%)\end{array}$} & \multicolumn{2}{|c|}{ Silicosis } \\
\hline & & & & No & $\%$ & & & & No & $\%$ \\
\hline $\begin{array}{l}<10 \\
10- \\
20- \\
\geqslant 30 \\
\text { Total }\end{array}$ & $\begin{array}{r}28 \\
137 \\
45 \\
20 \\
230\end{array}$ & $\begin{array}{l}27 \cdot 9 \pm 5 \cdot 0 \\
36 \cdot 1 \pm 6 \cdot 7 \\
46 \cdot 2 \pm 6 \cdot 4 \\
49 \cdot 9 \pm 6 \cdot 8 \\
40 \cdot 0 \pm 9 \cdot 9\end{array}$ & $\begin{array}{l}71 \cdot 4 \\
70 \cdot 8 \\
71 \cdot 1 \\
65 \cdot 0 \\
70 \cdot 4\end{array}$ & $\begin{array}{r}14 \\
52 \\
10 \\
6 \\
82\end{array}$ & $\begin{array}{l}50 \cdot 0 \\
40 \cdot 0 \\
22 \cdot 2 \\
30 \cdot 0 \\
35 \cdot 7\end{array}$ & $\begin{array}{r}71 \\
339 \\
108 \\
66 \\
584\end{array}$ & $\begin{array}{l}32.8 \pm 10 \cdot 0 \\
39 \cdot 1 \pm 7 \cdot 7 \\
46.1 \pm 7 \cdot 3 \\
52.5 \pm 6 \cdot 5 \\
42.6 \pm 8 \cdot 3\end{array}$ & $\begin{array}{l}67 \cdot 7 \\
78 \cdot 2 \\
66 \cdot 7 \\
71 \cdot 2 \\
74 \cdot 0\end{array}$ & $\begin{array}{c}20^{*} \\
158 \\
52 \dagger \\
44 \dagger \\
274 \dagger\end{array}$ & $\begin{array}{l}28 \cdot 2 \\
44 \cdot 6 \\
48 \cdot 1 \\
66 \cdot 7 \\
46 \cdot 9\end{array}$ \\
\hline
\end{tabular}

"b lower than a p 0.05 .

to higher than a p 0.01 .

Table 7 Prevalence of silicosis among examined workers versus their blood groups

\begin{tabular}{|c|c|c|c|c|c|c|}
\hline \multirow[t]{2}{*}{ Blood group } & \multirow[t]{2}{*}{ No examined } & \multirow{2}{*}{$\begin{array}{l}\text { Age }(y r) \\
(\text { mean } \pm S D)\end{array}$} & \multirow{2}{*}{$\begin{array}{l}\text { Duration of } \\
\text { exposure }(y r) \\
\text { (mean } \pm S D)\end{array}$} & \multirow{2}{*}{$\begin{array}{l}\text { Smokers } \\
(\%)\end{array}$} & \multicolumn{2}{|c|}{ Silicotics } \\
\hline & & & & & No & $\%$ \\
\hline $\begin{array}{l}\mathbf{O} \\
\mathbf{A} \\
\mathbf{B} \\
\mathbf{A B}\end{array}$ & $\begin{array}{r}296 \\
268 \\
185 \\
65\end{array}$ & $\begin{array}{l}39 \cdot 5 \pm 10 \cdot 0 \\
39 \cdot 4 \pm 10 \cdot 1 \\
37.6 \pm 10 \cdot 2 \\
41.5 \pm 8.6\end{array}$ & $\begin{array}{l}15 \cdot 9 \pm 7 \cdot 3 \\
16 \cdot 2 \pm 7 \cdot 0 \\
16 \cdot 0 \pm 7 \cdot 2 \\
16.9 \pm 6 \cdot 2\end{array}$ & $\begin{array}{l}67 \cdot 2 \\
80 \cdot 0 \\
72 \cdot 4 \\
72 \cdot 3\end{array}$ & $\begin{array}{r}147 \\
97 \\
80 \\
32\end{array}$ & $\begin{array}{l}497^{\mathrm{a}} \\
36 \cdot 2^{\mathrm{b}} \\
43 \cdot 2^{\mathrm{a}, \mathrm{b}} \\
49 \cdot 2^{\mathrm{a}, \mathrm{b}}\end{array}$ \\
\hline
\end{tabular}

a,bAll percentages for a given class of parent's consanguinity without common superscript differ significantly at $\mathbf{p}<0.05$.

development of silicosis in these families.

\section{Discussion}

The finding of silicosis in some families and not in others (table 1) suggests that there may be an inherited factor of resistance or susceptibility. Within each family this factor was so decisive in the development of the disease that it overshadowed the effect of duration of exposure to the dust (table 2). For example, there was no significant difference in the prevalence of the disease between older and younger brothers, cousins, and even far relatives (table 3) despite the significant difference in age and duration of exposure between older and younger family members (table 4). Little is known about family susceptibility to disease, ${ }^{2}$ and the influence of family genetics on the occurrence of silicosis has been little explored. ${ }^{1}$ A survey of many fluorspar miners and their families in Sardinia, however, showed evidence that family genetics might have determined a predisposition for some people to develop silicosis and for others to resist it. ${ }^{20}$ Furthermore, family susceptibility may have a role in the incidence of some respiratory diseases-for instance, tuberculosis. ${ }^{2}$

The degree of consanguinity of parents has also been shown, in the present investigation, to determine the predisposition to the occurrence of silicosis. Present data showed that the highest prevalence of silicosis was observed among sons whose parents were cousins. This close consanguinity probably rendered the sons more susceptible to the disease than when the parents were far relatives or not related (table 5). Previous reports have indicated that consanguineous marriages give a chance for the recessive characters that are pathological to be homozygous and express themselves. ${ }^{21}$

Another factor shown in the present study to contribute to resistance to silicosis is the father's history of exposure to silica dust. Workers whose fathers had a history of exposure to silica dust were more resistant to the development of the disease than those whose fathers had no such history, despite the similarity of the duration of exposure to dust and smoking habits between both groups (table 6). Many fathers had a history of exposure to dust before their marriage. For example, the means of the average age at the beginning of exposure among many of the examined families $(1,4,6,8,9,14,17,25$, $27,29,32,33$ ) were below 21 (table 1). The "apparently" lower prevalence of silicosis among workers with fathers with no history of exposure to silica-bearing dust than those from fathers with a history of exposure (less than 10 years) (table 6) might be because some of the workers in the first group who develop respiratory ailments leave the work and change their jobs, while fewer workers in the latter group would do so because of their family ties with their occupation. It may thus be concluded that the father's exposure to silica dust bears some relation to the tolerance of their sons to such exposure and may, consequently, increase their resistance to development of silicosis. This observation supports the similar observation noted among workers exposed to flax dust. 4

The blood group of exposed workers seems to be associated with the development of silicosis. The 
prevalence of the disease was higher in workers with blood group $\mathrm{O}$ or $\mathrm{AB}$ than in those with blood group B and least in workers with blood group A. Among the many disorders reported to be affected by the individual's blood group, however, bronchiectasis has been reported to be associated with group A.10 No further data could be obtained from published reports.

Thus it may be concluded from the results of this and our previous study 4 that family susceptibility and occupational and family histories may have an important role in the development of occupational diseases in general. Also the fathers' occupational exposure may increase the tolerance of their sons to such exposure. Further studies are necessary, however, to elucidate this apparent tolerance, as well as the role of individuals' blood groups in the development of silicosis and other occupational diseases.

\section{References}

${ }^{1}$ Parkes WR. Occupational lung disorders. London: Butterworth, 1974:177.

${ }^{2}$ Hill JB, Hill HD. Genetics and human heredity. London: McGraw Hill, 1955:490.

${ }^{3}$ Metrakos M, Metrakos K. The mechanism of epilepsy. In: McLeoid JG, Lance JW, eds. Physiological approach to clinical neurology. London: Butterworth, 1975:278.

${ }^{4}$ Noweir MH, Amine EK, Osman HA. Epidemiological investigation of the role of family susceptibility and occupational and family histories in the development of byssinosis among workers exposed to flax dust. $\mathrm{Br} J$ Ind Med 1975;32:297-301.

${ }^{5}$ Hashem N, Abdel-Aal A. Gaz Egypt Pediatr Assoc 1960; 8:775-9.

- El-Sherbini AF, Assad FA. Longitudinal study of child growth during the first year of life in "Nay." II Nay community. Gaz Egypt Pediatr Assoc 1966;14:69-73.
7 Lenz F. Meaning of the statistically determined trial with consanguinity of parents. In: Bayers SH, ed. Papers on human genetics. New Jersey: Prentice Hall, 1963:16.

${ }^{8}$ Morton EN. Morbidity of children from consanguineous marriages. In: Steinberg AG, ed. Progress in medical genetics. New York: Grune and Stratton, 1961:261.

${ }^{9}$ Stern C. Consanguinity. Principles of human genetics. 2nd ed. San Francisco: Freeman and Company, 1960:369.

${ }^{10}$ Billington BP. A note on the distribution of ABO blood groups in bronchiectasis and portal cirrhosis. Med J Aust 1956;2:20-2.

11 Oliver MF, Geizerova H, Cumming RA, Heady JA. Serum cholesterol and $\mathrm{ABO}$ and rhesus blood groups. Lancet 1969; ii:605-7.

${ }^{12}$ Talbot S, Wakley EJ, Longman MGS. $A_{1}, A_{2}, B$ and $O$ blood groups, Lewis blood-groups and serum. Triglyceride and cholesterol concentrations in patients with venous thromboembolic diseases. Lancet 1972; i :1152-4.

${ }^{13}$ Mourant AE. Blood groups and diseases. Haematologia $1974 ; 8: 183-94$

14 Thurgman J, Zohak M, Modan B. ABO blood group system in schizophrenia. Israel Journal of Medical Schizophrenia 1975;11:491-2.

15 Aird I, Bentall HH, Mehigan JA, Faster Roberts JA. Blood groups in relation to peptic ulceration and carcinoma of colon, rectum, breast and bronchus. $\mathrm{Br} J$ Ind Med 1954;3:315-9.

${ }^{16} \mathrm{Khattab}$ TM, Ismail AA. ABO blood groups in relation to rheumatic heart diseases. J Egypt Med Assoc 1960;43: 441-6.

${ }^{17}$ Khattab M, El-Gengehy M, Sharaf M. ABO blood groups in bilharzial hepatic fibrosis. J Egypt Med Assoc 1968;51 : 245-51.

18 Maxwell RDH, Maxwell KN. ABO blood groups and hypertension. Br Med J 1955;ii:179-82.

${ }^{19}$ Bohlig H. UICC/Cincinnati classification of the radiographic appearance of pneumoconiosis. Chest 1970;85: 57-65.

${ }^{20}$ Gedda L, Bolognesi M, Bandino R, Brenci G. Ricerche di genetica sulla silicos die minatori della sardegna. Lavaro Um 1964;16:555-62. (Cited in Parkes WR. Occupational lung disorders. London: Butterworth, 1974: 177.)

${ }^{21}$ Schull WJ. Effect of perinatal consanguinity. Pediatrics 1959;33:195-9. 